\title{
Minorities, immigrants and HIV/AIDS epidemiology
}

\author{
Concerns about the use and quality of data
}

\author{
M. HAOUR-KNIPE, F. DUBOIS-ARBER *
}

\begin{abstract}
A European Community concerted action charged with assessing AIDS prevention for migrants and/or ethnic minorities raised the problem of the quality and possibility for misuse of existing HIV and AIDS data. Basing statistics on the number of foreigners in a country is problematical as numbers are affected by variations in definitions and policies concerning immigration. Categorizing by ethnic origin raises serious definitlonal problems. For the numerator, epidemiology must be based on AIDS case data since systematic HIV testing of migrants is excluded on both practical and human rights grounds, but there are reasons for both over- and under-reporting of AIDS in migrant groups. Undertying issues of stigmatization and of racism are discussed. While there is need for improvement in the epidemiological data collected, both planning and evaluation of HIV/AIDS prevention programmes should more reasonably be based on proxy indicators, essentially those of knowledge, attltudes and behaviours, as well as on good ethnographies.
\end{abstract}

Key words: AIDS, ethnic origin, HIV, migrants

\begin{abstract}
A search charged with assessing HIV/AIDS prevention for migrants and ethnic minorities (Haour-Knipe 1991) described the situation in 12 European countries (Belgium, France, Germany, Greece, Italy, The Netherlands, Norway, Portugal, Spain, Sweden, Switzerland and United Kingdom). Two major inter-related themes were identified: the problem of targeting HIV/AIDS prevention activities without simultaneously stigmatizing an already marginal group and the (mis) use of epidemiological data concerning HIV and AIDS. The problems around the quality and use of existing epidemiological data concerning migrants are discussed here.
\end{abstract}

\section{WHY MIGRANTS?}

'Migrants' were loosely defined to include asylum seekers and sojourners as well as more permanent immigrants. All European countries have foreign or migrant populations (figure).

Official figures show that in 1990, Germany had the largest foreign population among European countries, with over 5 million foreign residents, followed by France with over 3.5 million and the UK with just under 2 million. In percentages, Switzerland had the highest pro-

- M. Hoour-Kripe, coordinator of European Community Concerted Action Work Group Assessing ADS Prevention for Migrants and Travelters, Geneva. Switzerland

F. Dubots-Arber, Coordinator of European Community Concerted Action Assessing HN/AJDS Prevention Strategies, University Institute of Sodal and Preventive Medikine, Lausanne, Switzerland

Correspondence: M Haour-Knipe, 5 Rue St. Ours, 1205 Geneva, Switzerland portion of foreign residents (16.3\%), followed by Belgium (9.1\%) and Germany (8.2\%).

Particularly at their inception, some AIDS prevention programmes for migrants or ethnic minorities were more or less explicitly based on the idea that they may be disproportionately affected or are at particular risk, as seems to be the case in the USA (Hopkins 1987, Gayle et al. 1990, Brundage 1991. Thomas \& Quinn 1991). While this may not necessarily be the case in Europe, there are several reasons why migrants should be of concern. First, by moving from one country to another, migrants are particularly affected by world-wide differences in both HIV patterns and prevention efforts: being in a high incidence country with a low level of prevention knowledge can be dangerous. Second, as the

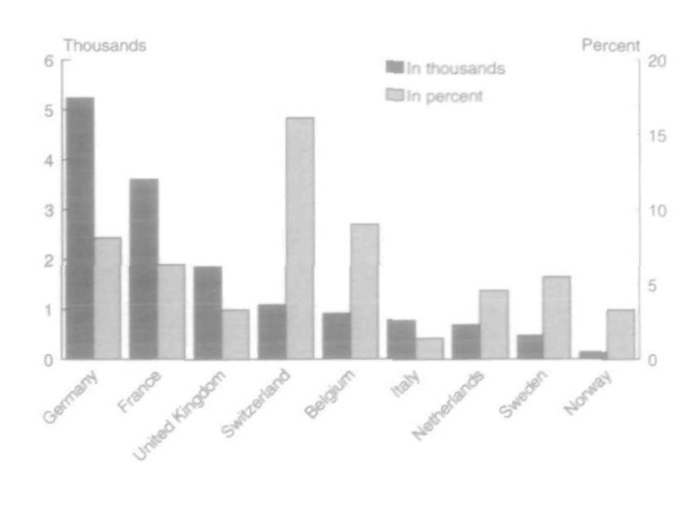

Figure Foreign population in selected European countries, 1990 Source: OECD, Trends in International Migration 
target year 2000 for 'health for all' approaches, it is increasingly evident both that social inequalities in health persist and that on the world level HIV and AIDS are distinctly related to them (Ramalinguaswami 1992). Some migrants or ethnic minority peoples may be among the least privileged members of the societies in which they are living and migrant health often falls between gaps of countries programmes, particularly where prevention is concerned. Third, the situation (Zwi \& Cabral 1991) of some migrants or members of ethnic minorities may lead to potential exposure to risk due to

- lack of access to information and to health care;

- difficulties in comprehending prevention messages, because of language difficulties, but more importantly because of profoundly different understandings and approaches to sexuality or to relationships between the sexes;

- particularities in living situations, for example, because of legal restrictions on family reunification, which may favour transitory sexual relationships;

- social and economic difficulties which could lead to such risk behaviours as clandestine prostitution or injecting drug use.

The members of the European Community Concerted Action Work Group attempted to determine whether the epidemiological data existed to assess HIV/AIDS prevalence and exposure to risk, to judge the quality of existing data and whether and how it might be used to evaluate both needs and the programmes designed to meet defined needs. HIV and/or AIDS data concerning foreigners or ethnic minorities was available for nine countries for 1989, but was too fragmentary and biased to be of use, for the reasons discussed in the following sections.

\section{WHO IS A FOREIGNER?}

The closer one looks the harder it is to define who is a foreigner. Both the United Nations (1991), and the Organization for Economic Co-operation and Development (1992) now publish migration statistics, but with provisos as to both their quality and comparability among countries. The OECD statistics given in the figure concern nationality, while the UN database concerns place of birth. The former is usually based on population registers monitoring people going into and out of the country and the data is thus entirely dependent on the quality of recording. The OECD notes, for example, that departures are generally less well recorded than arrivals. Data concerning place of birth comes from census information and quality is inversely related to the marginality of the populations being counted. Although attempts are being made to standardize data collection procedures, it is not presently possible to cross-relate between foreign born and foreign. An example of the magnitude of the difference comes from two of the countries presented in the figure. In 1990 , Sweden had 480,000 residents of foreign nationality, but 790,000 foreign born residents. The different ways of counting almost double the numbers for France, too. In 1982 France had 3,680,000 residents of foreign nationality, but $6,001,000$ foreign born.
Both ways of counting are subject to bias. By definition, established figures concern only registered foreigners and an increasingly large, but unknown, number of clandestine residents must be added to the totals. Neither way of counting takes into account asylum seekers or such factors as having more than one place of residence.

As for nationality, country policies in granting of citizenship skew the data considerably. While most northern European countries recruited labour in the 1960 s and the mean overall length of stay of foreign workers in EC countries is now more than 13 years (Callovi 1990), subsequent policies may be quite different. Germany, for example, still refers to the people recruited from Turkey 20 years ago not as immigrants, but as 'guest workers' (Marie 1990) and many of Switzerland's foreign residents have been living in the country for two generations without requesting citizenship. In contrast, France and Belgium accord citizenship relatively more easily (OECD 1992). Thus, the Turkish migrant worker in Switzerland may be foreign while his twin brother in Belgium may be Belgian.

Colonial heritage affects immigration statistics in several European countries, as in the UK, where workers were recruited mainly from former colonies whose inhabitants were British citizens until the matter came up for vivid debate in the 1970s (Marie 1990). In several European countries people born in former colonies, who may come from very different cultural backgrounds, are nationals by both ways of counting.

In contrast, culturally similar people born in neighbouring countries are at the moment of different nationality, although approximately five million of Europe's current 'foreigners' are soon to become demographic artefacts when citizens of one EC country living in another are no longer considered foreign (Callovi 1990).

In sum, a global category 'foreign' tells nothing about linguistic, cultural and social differences that may cause problems in HIV/AIDS prevention.

\section{WHAT ABOUT ETHNIC ORIGIN?}

Since it is pertinent to know about health problems in various subgroups, health statistics in some countries, for example the UK, avoid the notion 'foreign' or 'resident' and instead list 'ethnic origin' (the three UK categories are black, Asian/Oriental and other/mixed). American sources also categorize ethnic minorities (the categories usually being black or African-American and Hispanic). Categorizing by race or by ethnic origin, although more appropriate for capturing cultural differences, poses other problems, most notably in definition. There is the problem, for example, of what should be done in cases of various degrees of mixing. What race, for example, should be assigned somebody with one black grandparent - or with two black grandparents (Wyatt 1991)? Replacing race with ethnic origin does not seem to help much. Hispanics in the USA may come from Mexico or from Spain or perhaps from both if one takes several generations into account. Along the same lines, the issue has not been addressed of how many generations in a country 


\section{•Author index}

A note from the editors: thanks to our referees (Editorial)

In memoriam Avi Yacar Ellencweig

Instructions for authors

\section{A}

Aarø, L.E., see: Klepp, K-I.

Abdulaziz Al-Sekait, M., L. Abdulrhman Al-Ansary, F. Al-Zamel. Prevalence of pathogenic intestinal parasites among Saudi rural schoolchildren

Abdulrhman Al-Ansary, L., see: Abdulazız Al-Sekait, $M$.

Al-Zamel, F., see: Abdulaziz Al-Sekait, M.

Alonso, J., see: Ruigómez, A.

Andrés López Fernandez, L., see: Del Mar García Calvente, $M$.

Antó, J.M., see: Ruigómez, A.

Ashton, J.R., see: Vaandrager, H.W.

Aymé, S., see: Julıan-Reynier, C.

B

Barbuti, Salvatore, see: Germınarı, Cinzia

Battısta, R.N., see: Julian-Reynier, C.

Bengtsson Agostino, M., A.L. Rum,

$\mathrm{V}$. Wahlberg. Women and men in the abortion situation: a study in Italy and Sweden

Berg, J.E., A.T. Høstmark, P. Kierulf, S. Brudal, S.R. Berge. Coronary risk factors in middle-aged men as influenced by fish oils and smoking

Berge, S.R., see: Berg, J.E.

Bernheim, J., see: Green, M.S.

Bojan, F., see: McKee, $M$.

Boulton, M., see: Dawson, J.

Bretin, H., N. Job-Spira, B. Ducot, M. de Crécy, $\mathrm{M}$. Turshen, $\mathrm{A}$. Thébaud-Mony.

Discontinuance and acceptability of the pill, the IUD and injectable contraceptives: a prospective study in a département of Ile-de-France

Brookes, M., see: Dawson, J.

Brudal, S., see: Berg, J.E.

Buekens, P. Commentary: the moral debate about abortion (Viewpoint)

\section{C}

Calnan, M., S. Williams. Policies and practices for the assessment and management of risk factors for coronary heart disease prevention: the perspective of the general practitioner

Capper, S.A., see: Duncan, W.J.

Casabona, J., see: Vall Mayans, M.

Casparie, A.F., D. Post, W.H. van Harten, J.W. Gubbels. Differences in production between medical specialists: an inventory based on claims data to identify potential areas for quality-improvement activitıes (Short report)

Celentano, D.D., see: Peruga, A.

Chinitz, D.P., see: Ellencweig, A.Y.

Colomèr Revuelta, C., see: Vaandrager, H.W.

D

Dahl, E., P. Kjærsgaard. Soctal mobility and inequality in mortality: an assessment of the health selection hypothesis

Dawani, H., see: Janson, S.

Dawson, J., R. Fitzpatrick, G. Hart, M. Boulton, J. McLean, M. Brookes. Access to HIV testung for homosexually active men

De Crécy, $M$., see: Bretin, $H$.

Del Mar García Calvente, M., L. Andrés López Fernandez, E. Sánchez-Cantalejo. Identification of factors associated with deficient immunization coverage: an instrument to manage preventive health services

Döring, A., B. Filipiak, J. Stieber, U. Keil. Trends in oral contraceptive use in a Southern German population: results of the MONICA project Augsburg: surveys 1984/85 and 1989/90

Dubois-Arber, F., see: Haour-Knipe, M.

Duch, D. Commentary: the moral debate about abortion (Viewpoint)

Ducot, B., see: Bretin, $\mathrm{H}$.

Duncan, W.J., P.M. Ginter, S.A. Capper. Identifying opportunities and threats in public health

\section{E}

Elkeles, T., W. Seifert. Unemployment and Health-Impairments: longitudinal analyses for the Federal Republic of Germany

Ellencweig, A.Y., D.P. Chinitz. Israel's health system reform: the role of management in ensuring access and improving health status 
Elmén, H. Infant mortality: social inequality in a Swedish city

\section{F}

Figueras, Josep. Competition and planning in the National Health Service: the danger of unplanned markets / Calum Paton (Book review)

Filipiak, B., see: Döring, A.

Fitzpatrick, R, see: Dawson, J.

Forsberg, E., B. Starrin. Deinstıtutionalization and the 'long-term mentally ill': a Swedish case study

\section{G}

Garcia, J., see: Saurel-Cubizolles, M-J.

Garpenby, P. From ideology to reality: mental health care in Sweden (Short report)

Germinario, Cinzia, Michele Quarto, Salvatore Barbuti, Donato Greco, Salvatore Squarcione, Sergio Lo Caputo. Public health emergency in Albania (Letter to the editor)

Ginter, P.M., see: Duncan, W.J.

Gleave, R. Images of contracting for the mental health service

Greco, Donato, see: Germinario, Cinzia

Green, M.S., J. Shaham, J. Green, G. Harari, J. Bernheim. Association of passive smoking with increased coronary heart disease risk is not explained by elevation of leucocyte count

Green, J., see: Green, M.S.

Gubbels, J.W., see: Casparie, A.F.

Gundi, A. Analysing Health Systems: A

Modular Approach / Avi Yacar Ellencweig

(Book review)

Gunning-Schepers, L.J., see: Stronks, K.

\section{$\mathrm{H}$}

Hannan, P., see: Klepp, K-I.

Haour-Knipe, M., F. Dubois-Arber. Minorities, immigrants and HIV/AIDS epidemiology: concerns about the use and quality of data

Harari, G., see: Green, M.S.

Hart, G., see: Dawson, J.

Hashimoto, H., see: Nagal, $M$

Hemminki, E., see: Makkonen, K.

Hickey, D., see: Oakley, A.

Hirohata, T., see: Nagai, $M$.

Hostmark, A.T., see: Berg, J.E.
Jacobs jr., D.R., see: Klepp, K-I.

Janson, S., H. Dawani, H. Insheiwat. Family life conditions in urban Jordan and its sınificance for birthweight and child loss

Job-Spira, N., see: Bretin, $H$.

Jones, R.B. An evaluation of the character of the moral debate about abortion (Viewpoint)

Feasibility and performance of post-mortem examination to determine the aetiology of congenital anomalies in a population of 1019 foetal and perinatal deaths

\section{K}

Karisto, A., see: Lahelma, E.

Keil, U., see: Döring, A.

Kierulf, P., see: Berg, J.E.

Kjærsgaard, P., see: Dahl, E.

Klepp, K-I., R.J. Ulvik, S.B. Matthiesen, P. Hannan, D.R. Jacobs jr., L.E. Aarø. Cholesterol screening: observed cholesterol reduction in a prospective study in Norway

Koelen, M.A., see: Vaandrager, H.W.

Kondo, M., see: Nagai, M.

Kronmal, R.A., see: Sherry, B.

\section{L}

Lahelma, E., A. Karssto. Morbidity and social structure: recent trends in Finland the elderly / W.E. Waters, E. Heikkinen, A.S. Dontas (eds.) (Book review)

Lean, M.J.E. What did your baby eat yesterday? (Letter to the editor)

Light, D.W. Escaping the traps of postwar western medicine: how to maximize health and minimize expenses

Lo Caputo, Sergio, see: Germinario, Cinzia

\section{M}

Maarse, J.A.M. The insurer-provider relationship in health care: from administration to strategic management: the Dutch case

Maarse, J.A.M., A. van der Horst, EJ.E. Molin. Hospital budgeting in the Netherlands: effects upon hospital services

Macintyre, Sally. Health and class: the early years / C. Power, O. Manor, J. Fox (Book review) 
Mackenbach, J.P. Inequalities in health in the Netherlands according to age, gender, marital stans, level of educarion, degree of urbanization, and region

Makkonen, K., E. Hemminkı, R. Tuimala. Contraception in Finland - with a focus on IUDs

Matsumoto, Y., see: Nagai, M.

Matthiesen, S.B., see: Klepp, K-I.

McKee, M., F. Bojan, C. Normand on behalf of the tempus consortium for a new public health in Hungary. A new programme for public health training in Hungary

McKee, M., see: Stephenson, P.A.

McLean, J., see: Dawson, J.

Melling, R. Sticks or carrots? The challenge of implementing a management development strategy in the new NHS

Molin, E.J.E., see: Maarse, J.A.M

Monrad Aas, I.H. Health Service Qualıty: An Introduction to Quality Methods for Health Services / John Øvretveit (Book review)

\section{$\mathbf{N}$}

Nagai, M., T. Hirohata, Y. Matsumoto, H. Hashımoto, M. Kondo, K. Ozasa, et al. A case control study of female systemic lupus erythematosus in Japan

Navarro, V., see: Peruga, A.

Normand, Charles. Planned markets and public competition: strategic reform in northern European health systems / R.B. Saltman, C. von Otter (Book review)

Normand, C., see: McKee, M.

$\mathrm{O}$

Oakley, A., A.S. Rigby, D. Hickey. Women and children last? Class, health and the role of the maternal and child health services

Oakley, A., L. Rajan. What did your baby eat yesterday? Social factors and infant feeding practices

Oakley, A., L. Rajan. Reply / What did your baby eat yesterday (Letter to the editor)

Olsen, J. Some consequences of adoptıng a conditional determınistic causal model in epidemiology

Osore, $\mathrm{H}$. The role of revolving drug funds in strengthening $\mathrm{MCH} / \mathrm{PHC}$ services in Liberia

Ostrowska, A. From totalitarianism to pluralism in Poland: problems of transformation on the health scene
$112 \varnothing$ vretveit, J. Purchasing for health gain: the problems and prospects for purchasing for health gain in the 'managed markets' of the NHS and other European health systems

249 Ozasa, K., see: Nagai, $M$.

$\mathbf{P}$

38 Peruga, A., D.D. Celentano, V. Navarro. Social, demographic and attitudinal correlates of AIDS

60 Knowledge in the general population of Spain

Post, D., see: Casparie, A.F. 292

Potts, M. Commentary: the moral debate about abortion (Viewpoint)

Public health research in Switzerland (Erratum)

$199 Q$

Quarto, Michele, see: Germinario, Cinzia

R

Rajan, L., see: Oakley, A.

Rigby, A.S., see: Oakley, A.

Rodés, A., see: Vall Mayans, $M$.

Romito, P., see: Saurel-Cubizolles, M-J.

Rosén, U., see: Sundquist, J.

Ruigómez, A., J. Alonso, J.M. Antó. Functional capacity and five-year mortality in a sample of urban community elderly

Rum, A.L., see: Bengtsson Agostino, M.

$\mathrm{S}$

Salas, T., see: Vall Mayans, M.

a, Reijo. Describing and explainin

differences in the length of hospital stay /

G.P. Westert (Book review)

Sánchez-Cantalejo, E., see: Del Mar García

Calvente, $\mathrm{M}$.

Saurel-Cubizolles, M-J., P. Romito, J. Garcia.

Description of maternity rights for working women in France, Icaly and in the United Kingdom

Seidel, H.J. Healthy Cities / John Ashton (ed.)

210 (Book review)

Seifert, W., see: Elkeles, T.

Shaham, J., see: Green, M.S.

Shea, Steven. Health for All Policy in Finland /

World Health Organizanon (Book review)

Sherry, B., A.L. Smith, R.A. Kronmal.

A case-control assessment of risk factors for

Haemophilus influenzae type B meningitis

(Short report)

Smith, A.L., see: Sherry, B.

Squarcione, Salvatore, see: Germinario, Cinzia
8

3

69


Starrin, B., see: Forsberg, E.

Startin, B. Participatory Action Research /

William Foote Whyte (ed.) (Book review)

Starrin, B. Action and Knowledge: Breakıng the Monopoly with Participatory Action Research /O. Fals-Borda, M. Anısur Rahman (eds.)

(Book review)

Stein, Hans. Can supra-national public health strategies improve the health status of national populations? (Editorial)

Stephenson, P.A., see: Svensson, P-G.

Stephenson, P.A. Health Systems Research

Training Serıes (Book review)

Stephenson, P.A., M. McKee. Look Twice (Editorial)

Stieber, J., see: Döring, A.

Strong, Phil. Whose standards? Consumer and professional standards in health care / Charlotte Williamson (Book review)

Stronks, K., L.J. Gunning-Schepers. Should equity in health be target number 1 ?

Sundquist, J., U. Rosén. The influence of social surroundings on consultation of private care, emergency department, hospital out-patient departments, and primary health care: 1384 consultations made by a defined population in a residential area

Svensson, P-G., P.A. Stephenson. A note from the Editorial Office (Editorial)
Thébaud-Mony, A., see: Bretin, $H$.

Tuimala, R., see: Makkonen, $K$.

Turshen, $M$., see: Bretin, $H$.

3

Ulvik, R.J., see: Klepp, K-I.

Vaandrager, H.W., M.A. Koelen, J.R. Ashton, C. Colomèr Revuelta. A four-step health promotion approach for changing dietary patterns in Europe

Vall Mayans, M., T. Salas, A. Rodés, J. Casabona. Cross-sectional survey of hospital HIV/AIDS care in Catalonia, 1990

Van der Horst, A., see: Maarse, J.A.M.

Van Harten, W.H., see: Casparie, A.F.

\section{W}

Wahlberg, V., see: Bengtsson Agostino, M.

Wendte, J.F. The new Eastern Europe: social policy past, present and future / B. Deacon et al (Book review)

Williams, S., see: Calnan, $M$.

\section{•-Subject index}

\section{A}

\section{abortion}

Bengtsson Agostino, M.

Buekens, $P$.

Duch, D.

Jones, R.B.

Potts, $M$.

accreditation

Melling, R.

activities of daily living

Ruigómez, A.

\section{AIDS/HIV}

Dawson, J.

Haour-Knipe, $M$.

Peruga, A.

Vall Mayans, $M$.

\section{B}

\section{Belgium}

Buekens, P. birth spacing

Janson, S.

blood count

Green, M.S.

144

144

141

143

$\mathrm{C}$

causality/causal models

Olsen, J.

child health

Abdulaziz Al-Sekait, M. 232

Janson, $S$.

Oakley, A.

Oakley, A.

Sherry, B.

cholesterol

Klepp, K-I.

chronic illness

Forsberg, E.

Mackenbach, J.P. community medicine

Light, D.W.

community involvement

Vaandrager, H.W.

competition

Ellencweig, A.Y.

Light, D.W.

congenital malformations Julian-Reynier, C.

consanguinity

Janson, S. contraception see: family planning

coronary heart disease

Berg, J.E.

Calnan, $M$.

Green, M.S. 
D

data quality

Haour-Knipe, M

decision making

Duncan, W.J.

deinstitutionalization

Forsberg, E.

Denmark

Olsen, J.

E

elderly

Ruigómez, A

emergency department

Sundquist, J.

environmental interventions

Vaandrager, H.W.

ethnicity

Haour-Knipe, $M$.

Europe/European comparisons

Bengtsson Agostino, M.

Haour-Knipe, $M$

Saurel-Cubizolles, M-J.

Stein, $\mathrm{H}$.

Vaandrager, H.W.

evaluation

Julian-Reyner, C.

\section{F}

family planning

Bengtsson Agostino, $M$.

Bretin, $\mathrm{H}$.

Döring, A.

Makkonen, $\mathrm{K}$.

financing

Osore, $\mathrm{H}$

Finland

Lahelma, E

Makkonen, $\mathrm{K}$.

fish oils

Berg, J.E.

France

Bretin, $\mathrm{H}$.

Julian-Reynier, C.

G

genetics

Julıan-Reynier, C.

Germany

Döring, A.

Elkeles, $\mathrm{T}$.

\section{$\mathbf{H}$}

health care utilization

259 Sundquist, J.

health for all

54 Stein, $\mathrm{H}$

health gain

137 Øvretveit, J.

health insurance

204 Ellencweig, A.Y.

Light, D.W.

Maarse, J.

health planning

165 Duncan, W.J.

health policy

188 Calnan, $M$.

Light, D.W.

Stein, $\mathrm{H}$

Stronks, K.

health promotion

Calnan, $M$.

Vaandrager, H.W.

254

259

health satisfaction

Elkeles, $\mathrm{T}$.

health selection

193 Dahl, E.

health services reforms

153 Ellencweig, A.Y.

Forsberg, E.

Ostrowska, A.

Øvretveit, J.

Stronks, K.

242 health status

177 Elkeles, T.

249 Ellencweig, A.Y.

Ruigómez, A.

Stein, $\mathrm{H}$.

health systems

Light, D.W.

Ostrowska, A.

Stein, $\mathrm{H}$.

Haemophilus influenzae type $b$

Sherry, B.

homosexual men

Dawson, J.

hospital services/budgeting

Maarse, J.A.M.

Sundquist, J.

Vall Mayans, $M$.

Hungary

McKee, $M$. inequalities in health/

socioeconomic

Dahl, E.

124

188

Elmén, $\mathrm{H}$

Lahelma, E.

237

Mackenbach, J.P. 112

Stronks, K.

Svensson, P-G. 71

77 infant mortality

Elmén, $\mathrm{H}$.

237

infant feeding

Oakley, A.

injectable contraceptives

Bretin, $\mathrm{H}$

intersectoral collaboration

Vaandrager, H.W.

intestinal parasites

Abdulaziz Al-Sekait, M.

intrauterine devices

Bretin, $\mathrm{H}$.

Ellencweig, A.Y.

Japan

Nagai, $M$.

Jordan

Janson, S.

$\mathbf{L}$

leucocytes

Green, M.S.

Liberia

Osore, $\mathrm{H}$.

low birthweight

Janson, S.

\section{M}

management

Del Mar García Calvente, M. $\quad 97$

Duncan, W.J. $\quad 54$

Ellencweig, A.Y. $\quad 85$

264 Gleave, $R$. 92

Maarse, J.A.M. 181

Melling, R. 199

181 Øvretveit, J.

269 markets

Light, D.W. $\quad 281$

60

Øvretveit, J

maternal health services

Oakley, A. 220

Osore, $\mathrm{H}$. 133

immunization

Del Mar García Calvente, M. 
maternity rights/benefits Saurel-Cubizolles, M-J.

medical practice variations Casparie, A.F.

meningitis

Sherry, B.

mental illness/health care

Forsberg, E.

Garpenby, P.

Gleave, $\mathrm{R}$.

migrants

Haour-Knipe, $M$.

monitoring

Melling, R.

\section{$\mathrm{N}$}

necropsy

Julian-Reynier, C.

Netherlands

Casparie, A.F.

Maarse, J.A.M.

Maarse, J.A.M.

Mackenbach, J.P.

Stronks, K.

NHS

Gleave, $\mathrm{R}$.

Melling, R.

Øvretveit, J.

\section{Norway \\ Berg, J.E. \\ Dahl, E. \\ Klepp, K-I. \\ nutrition \\ Vaandrager, H.W.}

\section{$\mathrm{O}$}

oral contraceptives

Bretin, $\mathrm{H}$.

Dorring, A.

P

passive smoking

Green, M.S.

perceived general health Mackenbach, J.P.

perinatal mortality Julian-Reynier, C.

pharmaceuticals

Osore, $\mathbf{H}$.

physician consultation Elkeles, $\mathrm{T}$.

pluralism

Ostrowska, A.
Poland

48 Duch, D.

Ostrowska, A.

292 pregnant women's work

Saurel-Cubizolles, M-J.

290 prevention

Del Mar García Calvente, M.

Olsen, ].

296

92

259

199

primary care

Calnan, $\mathrm{M}$.

Del Mar García Calvente, $M$.

Osore, $\mathrm{H}$.

Sundquist, J.

providers

Calnan, M.

Casparie, A.F.

Gleave, R.

Maarse, J.A.M.

public health training

McKee, $M$.

292

72

181

112

104

purchasing/contracting

Gleave, R.

Øvretvelt, J.

Q

quality assurance

92 Casparie, A.F.

$77 \mathbf{R}$

159

124

38

regionalization

Ellencweig, A.Y.

regulation

Ellencweig, A.Y.

193 revolving drug funds

Osore, $\mathrm{H}$.

rural

Abdulaziz Al-Sekait, M.

\section{$\mathrm{S}$}

Saudi Arabia

Abdulaziz Al-Sekait, M.

14 screening

Calnan, $\mathrm{M}$.

Dawson, J.

112 Klepp, K-I

SIDS

153 Elmén, $\mathrm{H}$.

smoking

133 Berg, J.E.

Green, M.S.

28 social class/

socioeconomic status

Dahl, E.

Oakley, A.

Oakley, A. social policy

144 Saurel-Cubizolles, M-J.

48

social reform

Ostrowska, A.

48

social environment/mobility

Dahl, E.

124

97 Elmén, $\mathrm{H}$.

204 Lahelma, E.

Sundquist, J.

237

119

188

274 Spain

97 Del Mar Garcla Calvente, M. 97

133 Peruga, A. 8

188 Ruigómez, A. 165

Vall Mayans, M. 269

274 stillbirths

292 Julian-Reynier, C.

72 Sweden

Elmén, H. 237

Forsberg, E. $\quad 137$

60 Garpenby, P. 296

Sundquist, J. $\quad 188$

92 systemic lupus erythematosus

77 Nagai, M. 172

$\mathrm{U}$

unemployment

292 Elkeles, T.

United Kingdom

Calnan, $M$.

274

Dawson, J.

85 Gleave, R.

Jones, R.B.

Melling, R.

Oakley, A.

Oakley, A.

133 Øvretveit, J.

United States

232 Duncan, W.J.

Light, D.W.

Potts, M.

Sherry, B.

urine cotinine

Green, M.S.

274

264

38

\section{W}

women's health

Bengtsson Agostino, M. 254

237 Bretin, $\mathrm{H}$. 242

Buekens, P. 144

Döring, A. 177

159 Duch, D. 144

14 Jones, R.B. 141

Makkonen, K. 249

Nagai, $M$. 172

Potts, M. 143

124
18 
it might take before one might change ethnic origin or whether or not this might change again if the individual were to move on to a third country.

\section{WHAT TO MEASURE?}

Current data on HIV seropreualence is highly unlikely to reliably reflect the situation in the migrant population of a given nationality or ethnic origin in the host country. Systematic obligatory HIV testing is to be ruled out, both for human rights and practical reasons (Haut Comité de la santé publique 1992). Specific to migrant populations where HIV testing is concerned may be the situation of 'captive audiences', such as that of asylum seekers. Although no European country currently has a policy of compulsory testing of new immigrants, in some countries newly arriving asylum seekers may be 'offered' the possibility of HIV testing without knowing that they have the right to refuse. Difficult questions are raised in such a situation, for instance, how to do adequate follow-up counselling in the recipient's language, how the result might affect the individual's chances of being granted asylum status or whether or not to treat when chances are high that the person will be returned to a country where such treatment is not available. In sum, HIV seroprevalence is of dubious value either as a measure of needs among ethnic minority groups or as an outcome measure for evaluating programmes for minorities (Colebunders \& Heyward 1990).

Difficulties arise even when data is limited to AIDS cases (Blaxter 1991). In some countries, for example, data on foreign AIDS cases includes both residents and tourists. Ethnic minorities may be over-represented on public records, since in many countries a range of services are both officially and unofficially available to members of the local population who know how to use them. Migrants may thus appear on public records simply because they are easily identifiable and have neither the economic nor knowledge resources to go to caregivers who can assure complete confidentiality. On the other hand, there are valid reasons to think just the opposite: they may be under-represented among officially listed AIDS cases since they have less systematic access to testing and/or treatment.

At the end of the line, mortality data concerning migrants and stigmatized diseases may not be accurate. It has been noted, for example, that syphilis is likely to be underreported (Alderson 1981) and death certificate data concerning AIDS has been called into question, as doctors may be reluctant to list AIDS as cause of death (King 1989). Reporting of AIDS-related deaths may be higher if officials worry less about stigmatizing where foreign or minority patients are concerned. On the other hand, under-reporting among minorities due to ethnic misclassification has been found in the USA (Lindan et al. 1990). Higher incidences of drug use among minorities, also in the USA, confound the issue since deaths due to infections among injecting drug users with AIDS may not be counted as AIDS deaths (Des Jarlats \& Friedman 1988).
If such data as cause of death gives trouble, the reliability of data concerning such 'soft' issues as transmission route and when and where infection was acquired is even more difficult to evaluate. It is easy to imagine, for example, how the more subtle and intimate details concerning ethnic origin and mode of transmission could get lost when patient and information-taker do not share a common culture and language. When announcing a positive test result it may be tempting, for example, to take at least one easy route by classifying ethnic origin on the basis of skin colour and transmission mode on the basis of presumed continent of origin.

\section{DISCUSSION}

The problems discussed above raise doubts about the validity of cross-country comparisons related to AIDS and migrants. Is it then possible to use existing data to assess the situation within a given country to determine:

- are migrants, or some sub-groups among them particularly affected by HIV and by AIDS? and

- can data be used for programme planning and evaluation?

Before comparing migrants to the 'general population', the data available within a country should be carefully examined to identify and take into account measurement biases. In addition, the issues underlying these comparisons ought to be considered. Stigmatization and racism often underlie. Migrants or foreigners are particularly ready objects for stigmatization: epidemic disease has always been seen as coming from 'elsewhere' and so, of course, do migrants or foreigners. Stigmatization, in general, has been especially acute in the cases of HIV and AIDS. The problem at hand, HIV among minorities, puts all of the above concepts together in a particularly volatile mixture (Haour-Knipe 1993). Stated as such, the question 'Are migrants particularly affecred by HIV or AIDS?', for whatever reason it is asked, arouses fears of 'disease-bringing foreigners' and of drain on health care resources.

Two recent examples come from the UK and from Switzerland. In the former, in a letter in the Lancet (Chrystie et al. 1992), a team of virologists report a 9-fold increase in HIV prevalence among women attending antenatal clinics at one hospital in London. A high proportion of these women were classified in their notes as being from ethnic minority groups, largely of African origin. In the latter, the Swiss Federal Office of Public Health (1992) points out that more than $17 \%$ of the population living in Switzerland who are of foreign nationality are proportionately just as affected by AIDS as the Swiss population thereby calling for culture-specific prevention efforts.

The headline in a British newspaper concerning the former proclaimed 'Aids rise traced to migrants' (The Guardian, 7 February 1991), while about the latter a Swiss newspaper headed it's article 'Almost 20\% of AIDS cases due to foreigners' (Journal de Genève et Gazette de Lausanne, 2 September 1992). It would be unfair in either case to hold research teams responsible for journalistic excesses and neither newspaper story was as bad as the 
headlines would seem to indicate, but the damage is obvious and may hinder prevention efforts by raising adverse reactions in the concerned populations. More disclaimers and precautions in the original articles just might have helped anticipate misuse and head it off. Health officials need not only to work to improve the quality of the data being collected, but to carefully consider how it could be abused.

Another issue is that a global category of 'migrants' or 'foreigners' does not exist as an epidemiological entity any more than do 'general populations'. What do exist are subgroups, some with higher levels of risk, some without. Investigating the difference in the distribution of higherand lower-risk within the two populations focuses the problem more appropriately. Furthermore, while HIV and AIDS may disproportionately affect some minorities in developed countries, prevention campaigns should be based on the principle of universal right to know, rather than on a notion of particular risk. Just as 'risk group' logic has been rejected in favour of 'risk behaviour', migrants or ethnic minorities should never be considered a prioni 'at high risk' on the basis of presumed social origin. Even less should they be considered 'at risk' simply on the basis of geographical region of origin. Race should not be used as a proxy indicator for poverty, poor education or inadequate health care.

The quality of the available data concerning HIV and foreigners or ethnic minorities casts doubt on its usefulness. Several contradictory sources of bias in AIDS diagnoses among foreigners have been suggested. Existing epidemiological data is difficult if not impossible to use for international comparisons since category classifications are not necessarily equivalent. Case rates are variously calculated on the basis of current foreign nationality, of having been born abroad (in the two countries for which the data was available the second way of counting resulted in approximately twice as many foreigners) or on the basis of 'ethnic origin'. Those making the calculations on the national level may not be aware of the existence of the other ways of counting.

More importantly, AIDS case data comes too late approximately 10 years after the risk behaviour the programme would have set out to prevent. HIV prevalence data presents similar quality problems, as well as ethical problems around the basis for testing.

At the same time, good epidemiological data can be vital as an alarm signal to highlight potential and existing problem areas. Health care workers concerned with minority populations have argued that until the extent of problems is known they are handicapped in doing their work, that not collecting data can be another form of racism and that keeping secrets is a good way to inflate problems bigger than they might otherwise be. If reasonably valid epidemiological data showing lower or equal incidences of HIV or of AIDS among minority groups should not be taken to mean that a particular segment of the population has no need for prevention programmes, higher rates can reveal particular areas of need for research
One example, noticed by HIV/AIDS educators in both the UK and The Netherlands, concerns migrants from high prevalence countries, who need to know the risks of being infected on visits to their home countries (Dada 1991). Once foci of higher HIV infection within ethnic minority populations were identified and related to travel and unprotected sexual intercourse in given high prevalence countries, specifically targeted prevention efforts could be made. Similarly, migrants coming from or returning to low incidence countries should know about the problem and risks in higher incidence European countries. There is a significant risk that infected minority individuals from American and European countries introduce the syndrome when travelling to their home countries (Drucker 1990) as has already been demonstrated in Thailand (Apisuk 1990), Turkey (Wayling 1990), Jamaica (Figueroa 1990) and Romania (Hersh et al. 1991).

Thus, programme planning for HIV/AIDS prevention among migrants and ethnic minorities and the evaluation of such programmes, should more reasonably be based on proxy indicators, essentially those of knowledge, attitudes and behaviours, as well as on good ethnographies. Two examples can be drawn from Swiss studies of immigrant populations, in which it was found that programme planners definitions of concepts pertinent for AIDS prevention could be quite different from those found among minority groups (Fleury et al. 1991). Fidelity, for example, is not necessarily an adequate prevention measure among seasonal workers, for whom fidelity is based more on a common project of loyalty than on sexual exclusivity between spouses obliged by legal restrictions to live apart. In the second example, asylum seekers from some countries may incorrectly assume that commercial sex workers in the new country are state controlled, as they are in the home country and, thus, guaranteed to be free of disease. Knowledge and behavioural indicators are not only better adapted to understanding the nature of the problem, they are, after all, the factors on which prevention efforts are meant to intervene.

Material in this article was originally presented in poster form at the conference 'Association des épıdémiologistes de langue française', Lausanne, 25-27 March 1992. Different versions have been presented orally at two conferences: the Regional European Meeting of the International Epidemiological Association, Jerusalem, Israel, 14-19 February 1993 and the The Health of the Nation: The Ethnic Dimension, London, 21 June 1993.

\section{REFERENCES}

Alderson M (1981). International Mortality Statistics. London: MacMillan, pp.13-47.

Anonymous. Almost $20 \%$ of AIDS cases due to foreigners. Journal de Genève et Gazette de Lausanne, 2 Sept 1992.

Aplsuk C (1990). Challenges to national AIDS programs. Paper presented at the sixth International Conference on AIDS, San Francisco, 20-24 June.

Blaxter M (1991). AIDS: Worldwide Policies and Problems London: Office of Health Economics.

Brundage JF (1991). Epidemiology of HN infection and AIDS in the United States. Dermatol Clin 9:443-52. 
Callovi G (1990). L'Europe des douze au défi de l'immigration. L'Evénement europen: L'Europe et ses immigrés 11. Paris: Seuil pp.27-46.

Chrystie I, Palmer S, Kenney A et al. (1992). HN seroprevalence among women attending antenatal clinics in London. Lancet 339:364.

Colebunders R, Heyward W (1990). Surveillance of AIDS and HIV infection: opportunities and challenges. Health Policy 15:1-11.

Dada M (1991). Black communities: issues in AIDS education. Paper presented at the fifth Conference on Social Aspects of AIDS, London, 22 March.

Des Jarlais D, Friedman S (1988). HIV infection among persons who inject illicit drugs: problems and prospects. J Acquir Immune Defic Syndr 1:267-73.

Drucker E (1990). Epidemic in the war zone: AIDS and community survival in New York City. Int I Health Serv 20:601-15.

Figueroa P (1990). Challenges to national AIDS programs. Paper presented at the sixth International Conference on AIDS San Francisco, 20-24 June.

Fleury F, Haour-Knipe M, Ospina S (1991). SIDAMigration Prévention: Dossier portugais, dossier espagnol, dossier turc. Document 52.7. Lausanne: University Institute of Social and Preventive Medicine.

Gayle J, Selik R, Chu SY (1990). Surveillance for AIDS and HIV infection among black and Hispanic children and women of childbearing age, 1981-1989. MMWR CDC Surveill Summ 39:23-30.

Haour-Knipe M (1991). Migrants and Travellers Group Final Report. European Community Concerted Action on Assessment of AIDS/HIV Prevention Strategies. Document 72 Lausanne: University Institute of Social and Preventive Medicıne.

Haour-Knipe M (1993). AIDS prevention, stigma and migrant status. Innov Soc Sci Res 6:19-35.

Haut Comité de la santé publique (1992). Le dépistage et l'infection par le VIH. Paris: Ministère de la santé et de l'action humanitaire.

Hersh B, Popovici F, Apctrei R et al. (1991). Acquired immunodificiency syndrome in Romania. Lancet 338:645-9.
Hopkins D (1987). AJDS in minority populations in the United States. Public Health Rep 102:677-81.

King M (1989). AIDS on the death certificate: The final stigma. Br Med J 289:734-6.

Lindan C, Hearst N, Singleton J et al. (1990). Underreporting of minority ADDS deaths in San Francisco Bay area, 1985-86. Public Health Rep 105:400-4.

Marie C-V (1990). De L'Empire a l'Europe, un objet encombrant: L'immigration. L'Evénement européen: L'Europe et ses immigrés 11. Paris: Seuil pp.101-12.

Mihill C AIDS rise traced to migrants. Guardian, 7 Feb 1991.

Organization for Economic Co-operation and Development (1992). Trends in International Migration: SOPEMI 1992. Paris: OECD.

Ramalinguaswami $V$ (1992). The implications of AIDS in developing countries. In: Rossi GB, Beth-Giraldo $E$, Chiaco-Bianchi $L$ et al. (eds.). Science Challenging AIDS. Basel: Karger pp. 24-32.

Swiss Federal Office of Public Health (1992). Sida en Suisse: les Suisses ne sont pas seuts à être touchés. Berne: Division Epidémiologie et maladies infectleuses, Bulletin de l'Office fédéral de la santé publique 34:535-9.

Thomas S, Quinn S (1991). Evaluation of community-based AIDS education and risk reduction projects in ethnic and racial minority communities: a survey of projects funded by the US. Public Health Service. Evaluat Program Pian 14:247-55.

United Nations (1991). Demographic Yearbook 1989. New York: United Nations.

Wayling S (ed.) (1990). Current Status of HIVIAIDS Prevention and Control in the European Region: 1990 Update. Copenhagen: WHO European office.

Wyatt $G$ (1991). Examining ethnicity versus race in AIDS related sex research. Soc Sci Med 33:37-45.

Zwi A Cabral AJR (1991). Identifying 'high risk situations' for preventing AIDS. Br Med J 303:1527-9.

Received 22 February 1993, accepted 24 May 1993 